\title{
When Foreign Policy Meets Social Demands in Latin America*
}

\author{
Dawisson Belém Lopes (1) and Carlos Aurélio \\ Pimenta de Faria (2)**
}

\section{Abstract}

In order to introduce this special issue of Contexto Internacional, we first seek to provide a panoramic understanding of the Latin American political landscape. Next, we consider the new (and not so new) development strategies adopted by Latin American states, and their implications for foreign policy and international relations. Following this, we offer a brief review of the literature on Latin American foreign policy analysis and some of the theoretical and methodological challenges facing the study of Latin American international relations, thus providing a context for a deeper understanding of the contributions to this special issue. Put differently, our objective is to provide readers with a general idea of the reasons why foreign policy has met, should have met, or has been expected to meet social demands in contemporary Latin America.

Keywords: Latin America; Foreign Policy, Social Demands; Foreign Policy Analysis; International Relations.

* Received on 11 April 2016, and approved for publication on 13 April 2016.

** (1) Federal University of Minas Gerais, Belo Horizonte, MG, Brazil; dawisson@ufmg.br; (2) Pontifical Catholic University of Minas Gerais, Belo Horizonte, MG, Brazil; carlosf@ pucminas.br. 
Dawisson Belém Lopes and Carlos Aurélio Pimenta de Faria

\section{Introduction}

The period from 1945 to 1980 saw the emergence and decline of a social model in terms of which some European states assumed responsibility for providing social welfare. This approach, similar to the policies adopted by Franklin Delano Roosevelt in the USA in the early 1930s, sought to combine the observance of civil rights with policies aimed at promoting the integration of different social classes. In essence, this approach to social organisation represented a threat to laissez-faire liberal ideology as well as the state's progressive disconnect from external factors insofar as it began to play an active role in redistributing incomes, and providing the public with enhanced goods and services. Historically and institutionally, this approach became known as the welfare state (Faria 1998).

In about the same period, some peripheral countries (particularly in Latin America) went through an ideological cycle commonly referred to as developmentalism (Bielschowsky 2002). This involved adopting economic policies aimed at promoting private sector-led industrialisation, supplemented by entrepreneurial state activities aimed at promoting economic growth. Under the powerful influence of structuralist ideas conceived by the Argentinean economist Raúl Prebisch and the Economic Commission for Latin America and the Caribbean (ECLAC), Latin American developmentalism- led by Mexico and Brazil - was conspicuous for employing a strategy of import substitution. States did this to strengthen national productive sectors, and break the shackles of dependence on world capitalism.

In the early 1980s, the economic turbulence in developing countries and slower growth in developed countries in the aftermath of two global oil crises led to an endogenous crisis of the social state - the welfare state in the North, and the developmental state in the South. 
When Foreign Policy Meets Social Demands in Latin America

Combined with internal issues, exogenous factors led to a wave of neo-conservatism, and the notion of the minimal state became prominent. This gave rise to income concentration in many world regions, and, in the case of Latin America, an unprecedented increase in urban violence. It also encouraged innovative new approaches to collective problems, as well as certain state reforms. One of the most notable trends in this period was the development of new forms of public ownership and social control, at a time when signs of crisis developed in the social-bureaucratic state, and globalisation began to require new, more efficient and democratic modalities of public administration. In the period from 1980 to 1995 , broad structural state reforms were introduced across the entire Latin America, notably the aggressive liberalisation of trade, the deregulation of domestic financial markets and capital accounts, and the large-scale privatisation of state enterprises and assets. However, these neo-liberal reforms - commonly linked to the 'Washington Consensus' - did not enable Latin American states to play a more significant role in the world economy (UNDP 2004).

There was considerable turbulence on the continent in the 1990s. These were the first years of renewed democracy in Latin America and Eastern Europe after the fall of the Berlin Wall, the dismantling of the Soviet Union, the end of the Cold War, and the global spread of liberal-democratic ideas. It is no accident that, in the first half of the 1990s, several free trade experiments were inaugurated, not to mention the setting up of the World Trade Organization (WTO) in 1994, and the conclusion of many bilateral free trade agreements between Latin American countries and the rest of the world. There were clear signs of a new world to come. Given the depletion of state assets in Latin America, as well as recurrent financial crises (Brazil in 1999, Argentina in 2001), foreign investment in the region declined sharply. As a result, Latin American states became more dependent on foreign direct investment: from 1990 to 2001, their 
dependence on foreign investments rose from $6.7 \%$ to $28.2 \%$. A transition took place from the 'capitalist tutelage' model common during the Cold War to a competitive, globalised economic order of 'every man for himself'. Throughout Latin America, prices were stabilised in a very similar way. Central banks began to pursue inflation targets, as curbing inflation was the core conditionality imposed by the multilateral banks which would finance Latin American economies in times of economic turmoil (Belém Lopes 2007).

Structural reforms in Latin America resulted in increased foreign debt, with no social compensation. This trend was aggravated by the concentration of global income in OECD countries during the 20 years of structural reforms in Latin America (1980-2000). Labour relations deteriorated, and urban unemployment rates reached an all-time high. Although not confined to Latin America, growing unemployment in the region had far-reaching effects, aggravated by the lack of social assistance which would have protected workers against financial hardships. By the early 2000s, 'informal workers' comprised about $45 \%$ of the active Latin American labour force. Many economic adjustments were achieved by means of 'downsizing', resulting in huge reductions in working hours and wages. In these two decades, the number of the urban poor in Latin America grew by more than $100 \%$. Despite a slight improvement in wealth distribution in recent years, levels of social inequality remain high, and some Latin American countries still score more than 0.5 on the Gini index (Belém Lopes 2007).

As the failure of the neo-liberal model became increasingly apparent, a new movement developed towards reforming, or reconstructing, the state. The crisis of the state was not confined to the economic or financial dimension, nor to issues linked to administrative autonomy. Instead, it entailed the weakening of linkages between state and society, especially those between the public and private 


\section{When Foreign Policy Meets Social Demands in}

Latin America

sectors established under previous development strategies and institutional settings. Whereas in the past the state was regarded as a key factor in bringing about citizenship and order on the part of civil society, they (the state and civil society) were now expected to work together to bridge the gap between the political and social spheres. In sum, the state crisis induced a sense of urgency in the quest for efficiency and higher standards in rendering public services, which happened pari passu with the spread of democratic ideals all over the world. In reality, nobody seemed prepared to grapple with the most direct effects of globalisation at that time: growing international demands for better resource management on the one hand, and greater awareness of democracy and surveillance of governments on the part of the general public on the other. That is the moment when foreign policy started meeting social demands in Latin America on a more systematic basis.

With the benefit of hindsight, it can be argued that globalisation brought in its wake the need for improved governance aimed at overcoming social problems on a global rather than a local or national scale. However, as is well known, there is still no apparatus in the form of a central world authority to co-ordinate and regulate these processes. Given these dynamics, the 1990s became a stage for direct and bitter conflicts between transnational civil society movements (especially those concerned with issues of human rights and the environment), and the policies fostered by the neo-liberal economic institutions (notably the WTO, G-8, IMF and World Bank). The first rifts arose between the liberalising agendas of multilateral banks and business people on the one hand, and aggrieved social movements and NGOs on the other. It could be said that a hybrid post-liberal system was in the making, requiring worldwide managerial policies which were ambiguous and asymmetrical by definition. Moreover, decision-makers would now need to consider a wide range of actors — both old and new — with 
Dawisson Belém Lopes and Carlos Aurélio Pimenta de Faria

diametrically opposed views. One of the most notable and widespread effects of this complex emerging multilateralism in international relations has been the revision of certain positions held by the Bretton Woods institutions (particularly the World Bank) in favour of society-centred perspectives, and, in the domestic sphere, a proliferation of social programmes run by the state (Belém Lopes 2014).

In sum, after being regarded as 'villains' in the 1970s and 1980s, an epoch characterised by the collapse of Latin America's version of welfare state and the triumphant rise of neo-liberalism, certain states have found their social policies serving as important 'escape valves' and strategic instruments for managing political and economic crises. There may also be a correlation (albeit as yet unproven) in institutional democracies between comprehensive and successful social programmes and electoral rewards for the policy-makers concerned. This movement, which looked like a concerted enterprise in the first decade of the current century, has its roots in both world-systemic and regional/local factors. It is based not only on the way in which transnational social movements have come to pursue their novel demands from the second half of the 1990s onwards, but also on a greater willingness to entertain measures involving bilateral and regional co-operation, with Brazil as the main driving force. Brazil's newly crafted public diplomacy, particularly under the presidency of Luiz Inácio Lula da Silva, may be responsible for generating unprecedented convergences among the foreign policies of Latin American states (Belém Lopes 2014). However, competing approaches and models were also disseminated in order to radicalise post-liberal experiments, or revamp liberal strategies.

Against this background, we will seek, in the next section, to develop a greater understanding of the region's political landscape. Next, we will consider the new (and not so new) development strategies adopted by Latin American states, and their implications for foreign policy and 
When Foreign Policy Meets Social Demands in Latin America

international relations. Following this, we will offer a brief review of the literature on Latin American foreign policy analysis and some of the theoretical and methodological challenges that lie ahead for Latin American international relations as an academic field, thus providing a context for a deeper understanding of the contributions to this special issue of Contexto Internacional. Put differently, our objective is to provide readers with a general idea of the reasons why foreign policy has met, should have met, or has been expected to meet social demands in contemporary Latin America.

\section{Latin America's left turn (and reactions to it) in the 2000s}

It is reasonable to say that elections in Venezuela inaugurated Latin America's turn to the left and, 18 years later, were one of the first symptoms of its accelerated decay, signalling a possible reversal of the Latin American 'pink tide' (marea rosa). The victory of Hugo Chávez in the 1998 presidential elections was the first of a series that swept left-wing candidates, movements and parties into power. While a left-of-centre candidate had only been elected once before in regular elections in Latin America (Salvador Allende in Chile in 1970), ${ }^{1}$ Chávez's electoral triumph was followed by those of Ricardo Lagos in Chile (2000), Luiz Inácio Lula da Silva in Brazil (2002), Nestor Kirchner in Argentina (2003), Tabaré Vázquez in Uruguay (2004), Evo Morales in Bolivia (2005), Rafael Correa in Ecuador (2006), Daniel Ortega in Nicaragua (2006), Fernando Lugo in Paraguay (2008), and Maurício Funes in El Salvador (2009). The extent to which this 'leftist tsunami' (Flores-Macías 2010) was unexpected does not concern us here. We merely need to recall how unprecedented it was, and to remind ourselves that most of those leaders managed to be re-elected and/or to perpetuate the tide by successfully supporting their preferred successors. 
By March 2016, many observers and analysts were proclaiming the 'end of the progressive era' in Latin America, the reversal of the 'pink tide', or even the 'death of the Latin American left' . ${ }^{2}$ Empirical evidence abounded. In November 2015, a liberal, Mauricio Macri, won the presidential elections in Argentina, ending the Kirchnerist era in that country. Two weeks later, in December, the opposition gained control over the Venezuelan parliament for the first time since 1999, and in February 2016 Morales lost a referendum over whether he should be allowed to run for a fourth term as Bolivian president in 2019. Corruption scandals mushroomed in several countries, implicating even previously successful and prestigious administrations such as those in Brazil and Chile. Last but not least, US president Barack Obama adopted a 'good neighbourhood' policy towards Latin America, featuring the audacious restoration of diplomatic ties with Cuba as well as personal support for the new Argentine government. The future, however, will not get as much of our attention as the past and the present even if it promises another swing of the regional political pendulum, if not towards a renewed neoliberal hegemony, then at least towards a liberal foreign policy agenda.

For our purposes, it is important to recall that even if the use of the blanket term 'pink tide' is justified, diversity and plurality, both domestic and regional, should not be neglected if one wants to understand Latin American foreign policy (or policies) in this period; the new regionalisms that emerged (both post-liberal and anti-Bolivarian); and patterns of domestic support and discontent. The controversial thesis of the region's 'two lefts' is well known. While the term first appeared in an article written by the Venezuelan journalist Teodoro Petkoff (2005), the broader debate was sparked by an essay written in 2006 by the Mexican academic and former foreign minister Jorge Castañeda. His somewhat Manichean and normative account distinguished between two 'species' or currents 
When Foreign Policy Meets Social Demands in Latin America

of left-leaning government in Latin America: the 'right left', and the 'wrong' one. The first, which the author strongly supported, was said to be pragmatic, social-democratic, and aware of past mistakes by the left. The presidents of Chile, Brazil and Uruguay were cited as the finest examples of right left leaders. The wrong left, by contrast, was said to be populist, old-fashioned, and irresponsible, as exemplified by a new 'axis of evil' formed by the recently elected leaders of Venezuela, Bolivia and Ecuador.

Following this, some analysts tried to understand regional politics 'beyond good and bad' (Cameron 2009). However, these analytical and taxonomic efforts often led to new dichotomies, such as esquerdas renovadoras (reformist or renovation lefts) and esquerdas refundadoras (re-founding lefts; Silva 2010); social democrats and populists (Lanzaro 2007); democrats and authoritarians (Mires 2008); and leaders who were either possibilistas (people who worked within the range of possibilities) or 'outsiders' (Rouquié 2007). ${ }^{3}$ However, beyond these dichotomies, and as the distinguishing features of each national experience are revealed, one finds as many local left-leaning governments as there are countries making up the so-called left turn, because they emerged from distinct institutional settings; had different linkages with social movements (which themselves are a kaleidoscope); were formed through diverse coalitions; implemented their own policy mixes; espoused distinct degrees of anti-Americanism, if any; were more or less dependent on exports of a single commodity; were differently contemplated by the 'raw materials curse'; and sustained a relatively broad array of development strategies.

No matter the shades of pink in the Latin American 'pink tide', and recalling that political change was not the norm for the whole region during that period, there seems to be greater agreement when it comes to explaining its emergence. In terms of this canonical interpretation, the left turn should be understood as a feature of 
general redemocratisation in the region, which is widely regarded as an inevitable result of the high levels of inequality in the region. Redemocratisation also meant a drastic reduction of the power of the military in Latin American politics.

Other factors that played a role were the end of the Cold War, which released the left from the straitjacket of bipolarity, and forced it to revamp its agenda and electoral platform; general disillusionment with empty promises under neoliberal policies; and the fact that the USA seemed to lose interest in the region after the Washington Consensus and particularly after 9/11, which provided the George W Bush administration with a new enemy which the 'Washington playbook' (in Obama's later phrase) was so eagerly looking for.

The fate of Latin America's left turn has been closely associated with the commodities boom (or supercycle) of the 2000s, largely due to rising demand from emerging markets, notably China. In this respect, it should be recalled that the 'pink tide' emerged a bit earlier than the commodities boom. However, its success, reproduction, and later loss of popularity must certainly be understood as a byproduct of the commodity cycle's acceleration and decadence. The commodities boom not only enabled, at the domestic level, the introduction and extension of redistributive policies and massive state investments in infrastructure, but, at the regional and systemic levels, gave credibility to and provided material support for the goal of fostering South-South coalitions (Faria and Paradis 2013). The fact that it made Latin American countries less dependent on Bretton Woods institutions is also important, for symbolic and practical reasons.

But if those are the main independent variables that account for the general phenomenon, there is less agreement about the reasons why the various left-of-centre governments became more or less radical, and more or less market-friendly. If Latin American left-wing 
When Foreign Policy Meets Social Demands in Latin America

governments shared a commitment to social justice, wealth distribution, and participative or 'experimental' democracy (Pogrebinschi 2013), there were 'striking differences in the economic policies followed by leftist governments' (Flores-Macías 2010: 414). The most frequently quoted examples of countries favouring statist policies are Venezuela, Bolivia, and Ecuador, which extensively promoted nationalisation, price and foreign exchange controls, and land reform. The most prominent examples of pro-market experiments are Brazil, Chile and Uruguay, which to a large extent gave continuity to market orthodoxy. ${ }^{4}$ Weyland (2009) regards this divide as a divergent perception of the need to accept constraints on socioeconomic and political change:

The renovated, moderate left that currently governs Chile, Uruguay and Brazil has recognized a basic claim of political right, namely the need to respect constraints, especially the limitations arising from global capitalism and domestic market reform and from liberal, representative democracy. By contrast, the radical left repudiates these constraints, and seeks a bolder transformation (Weyland 2009: 146).

Actually, the differences in economic policies (and political rhetoric) have been explained in quite different ways. Analysts usually give priority to one of the following independent variables: (a) dissatisfaction with the market reforms of the 1980s and 1990s; (b) the degree to which the party system has been institutionalised; and (c) resource dependence. Resolving this controversy is beyond the scope of this introduction, and we merely present the main arguments below.

We start with the argument that emphasises the impacts of the market reforms implemented throughout Latin America in the 1990s. First, one should recall that the neoliberal recipe was not uniformly 
followed. Draconian reforms were implemented in Chile and Argentina, while Brazil and Venezuela adopted relatively mild adjustments. Furthermore, even when they were painful, neoliberal reforms in the region often received widespread popular approval, at least initially (Weyland 1998). Be that as it may, it is widely recognised today that the 'pink tide' was, at least in part, a product of the problems and failures of the market reforms adopted in the preceding decades. However, the relationship between dissatisfaction with neoliberalism and the re-emergence of the radical left is, as Weyland (2009) and others have shown, much less direct than is frequently claimed. Venezuela and Ecuador, two spearheads of the ' $21^{\text {st }}$-century socialism' doctrine, never fully implemented the neoliberal agenda.

The second variable frequently regarded as useful is the degree to which a party system is institutionalised. Flores-Macías (2010: 414) puts this as follows: 'Centripetal dynamics characteristic of institutionalised party systems make piecemeal reforms and the preservation of the status quo more likely, while centrifugal dynamics typical of party systems in disarray are conducive to unpredictable policies and significant economic transformations.' This is held to be because of differences in the kind of candidate more likely to capture power in each case, and the capacity of political parties to influence the policies proposed by the executive branch.

Even Weyland (2009), an eloquent exponent of the resource dependence theory, recognises that institutional factors help to explain the emergence of the two strands of left-wing governments in Latin America. Most notably, they largely account for both the moderate left in Chile and Uruguay and the radical outsiders in Venezuela and Ecuador. However, 'where party system strength changed rather quickly, as in Bolivia and Brazil, institutions are better seen as intervening variables than as true causes. Also, since institutional weakness is difficult to measure, institutionalism has 
When Foreign Policy Meets Social Demands in Latin America

some difficulty assessing the cause independently of its presumed effect' (Weyland 2009: 150).

This third explanation - resource dependence - is based on the 'rentier state' theory, and can be bluntly described as follows: abundant rents from commodities or raw materials undermine a country's commitment to economic orthodoxy (Flores-Macías 2010). According to Weyland (2009: 151), a more fundamental cause of the rise of the radical left is the availability of huge raw material rents in Venezuela, Ecuador and Bolivia. In the case of Brazil, Argentina and Uruguay, even if the natural resources bonanza of the $2000 \mathrm{~s}$ is regarded as important, they have not developed rentier economies. In Chile, a well-institutionalised and insulated stabilisation fund guarantees economic equilibrium no matter how copper revenues may vary. Again, we follow Weyland: 'The abundance in the ground and the resulting windfall gains make the neoliberal quest for wealth creation through productivity, efficiency, and competitiveness look unnecessary' (Weyland 2009: 151). Then, political will and voluntarism can reign unchecked, free of any constraints.

But market-friendly versus statist left-wing governments is not the only great divide in Latin America's 'pink tide', as suggested by the set of dichotomies cited earlier. Before concluding this section, we need to comment briefly on the claim that most, if not all, of contemporary Latin American governments share a commitment to participative or 'experimental' democracy. Torre (2013: 28) argues that the 'regimes of Hugo Chávez, Evo Morales and Rafael Correa can simultaneously be conceived as a threat and as a corrective to liberal democracy'. Like many others, he goes on to characterise them as a threat. The reasons are well known: their governments 'undermine the institutions that guarantee contestation, pluralism, and civil liberties'; concentrate power in the executive; and selectively deny civil and political liberties to some groups and 
individuals. This is why a considerable number of scholars and commentators define these regimes as authoritarian.

Besides the normative issues, however, attention should be paid to the way in which Torre (2013) interprets their distinct patterns when it comes to fostering participation. In Bolivia, Morales - who was first elected during rising popular protests - is constrained by social movements both in respect of his policies as well as his attempts to serve as the 'voice of the unitary people'. In that country, participation is usually understood from the bottom up; as a result, grass-roots movements have not lost their strength or autonomy, and the government still relies on popular mobilisation during conflicts with the opposition. In Ecuador, Correa became president at a time when the indigenous movement was in crisis. His technocratic leadership style is another sign that the president, who is widely regarded as a populist, struggles to present a popular profile. As Torre has noted, 'His government did not organize the subaltern beyond elections, and has not promoted mechanisms of participatory democracy at the local and community levels' (2013: 28). As popular social movements were relatively weak in Venezuela, Chávez fostered the organisation of the subalterns from the top down. The fact that opposition was stronger than in Ecuador was an additional incentive for Chávez to organise popular sectors. While participation in Venezuela was induced from the top down, 'citizens use these organisations to try to push their autonomous agendas' (Torre 2013: 20).

\section{Reclaiming and proclaiming the state in post-neoliberal Latin America}

The adjective 'post-neoliberal' has been widely employed to characterise the governments and policies of Latin America's left turn. In fact, it is arguable whether anti-neoliberal rhetoric was 
When Foreign Policy Meets Social Demands in Latin America

adopted by all the movements, parties and leaders of the 'pink tide'. Nevertheless, as Panizza warns:

( ... ) elements associated with a neoliberal agenda have been incorporated to a larger or lesser extent into left-of-centre governments in the region, such as low inflation rates and fiscal deficit control, combat to governmental inefficiency, economic opening up, and a relatively market-friendly attitude, especially towards foreign direct investments (Panizza 2006: 10$)^{5}$

Be that as it may, if the distinctive feature of neoliberalism was a systematic neglect of the state, Latin America's left turn was certainly characterised by a 'return of the state', which came to be regarded, as it had been during the heyday of dependency theory and developmentalism in the region, as a crucial and strategic instrument for the promotion of both social and economic development. This is why the development strategies adopted by left-wing governments were so often defined as a 'new developmentalism' (Bresser-Pereira 2009) or 'neostructuralism' (ECLAC 2007). If the disillusionment with the unfulfilled promises of neoliberalism meant increased support for the Latin American left at the ballot box, new developmentalism constituted much of its rationale, while the commodities bonanza gave governments the means to implement it.

But the state was not only reclaimed in Latin America; it was also lauded, sometimes in mantra-like fashion, for its expected capacity to promote social inclusion and sustained economic development (through massive investments in infrastructure and counter-cyclical economic policies), and craft 'real' sovereignty or even, in the case of the so-called 're-founding' governments, 'the second and definitive independence of their nations and even of their continent' (Torre 2013: 43). However, while anti-neoliberalism became the dominant discourse in the region, some countries - notably 
Colombia and Mexico, and, more ambiguously, Peru and Chile continued to endorse the liberal creed.

Bresser-Pereira (2009: 16) has defined new developmentalism as:

(...) a set of values, ideas, institutions, and economic policies through which, in the early $21^{\text {st }}$ century, middle-income countries seek to catch up with developed countries. It is not an economic theory but a strategy; it is a national development strategy, based mainly on Keynesian macroeconomics and development economics. It is a set of ideas that enables developing nations to reject rich nations' proposals and pressures for reform and economic policies, like capital accounts liberalization and growth with foreign savings, in as much as such proposals are neo-imperialist attempts to neutralize the economic growth of competing countries.

The tables below compare the main characteristics of old and new developmentalism (Table 1), and the growth strategy advocated by the Washington Consensus versus the strategy defended by new developmentalism (Table 2).

\section{Table 1}

Old and new developmentalism

\begin{tabular}{ll}
\hline Old developmentalism & New developmentalism \\
\hline $\begin{array}{l}\text { State-led industrialisation, based on } \\
\text { import substitution. }\end{array}$ & $\begin{array}{l}\text { Export-led industrialisation, combined with } \\
\text { strong domestic markets. } \\
\text { A leading role for the state in } \\
\text { enforcing savings and making } \\
\text { investments. }\end{array}$ \\
$\begin{array}{l}\text { The state creates investment opportunities, } \\
\text { and reduces economic inequalities. }\end{array}$ \\
$\begin{array}{l}\text { formulated. } \\
\text { Inconsistent attitude to budget } \\
\text { deficits. }\end{array}$ & $\begin{array}{l}\text { Industrial policy is subsidiary; the essential } \\
\text { feature is a competitive exchange rate. }\end{array}$ \\
Relative complacency about inflation. & Ro complion of fiscal deficits. \\
\hline
\end{tabular}

Source: Bresser-Pereira (2009: 21). 
When Foreign Policy Meets Social Demands in Latin America

\section{Table 2}

Growth strategies compared

\begin{tabular}{|c|c|}
\hline Washington Consensus & New developmentalism \\
\hline $\begin{array}{l}\text { No economic role for the nation or for } \\
\text { national development strategies. }\end{array}$ & $\begin{array}{l}\text { The nation is the main agent defining the } \\
\text { national development strategy. }\end{array}$ \\
\hline $\begin{array}{l}\text { Reforms that reduce the size of the state, } \\
\text { and deregulate markets. }\end{array}$ & $\begin{array}{l}\text { Reforms that strengthen the state, and } \\
\text { regulate markets. }\end{array}$ \\
\hline $\begin{array}{l}\text { The fundamental institutions for } \\
\text { promoting economic growth are property } \\
\text { rights and contracts. }\end{array}$ & $\begin{array}{l}\text { The key institution for promoting growth is } \\
\text { a national development strategy. }\end{array}$ \\
\hline $\begin{array}{l}\text { A minimal role for the state in capital } \\
\text { investment and industrial policy. }\end{array}$ & $\begin{array}{l}\text { A moderate role for the state in capital } \\
\text { investment and industrial policy; a major } \\
\text { role in the redistribution of wealth. }\end{array}$ \\
\hline $\begin{array}{l}\text { Not based on structural economic } \\
\text { theories. }\end{array}$ & $\begin{array}{l}\text { Tendency to overvalue the exchange rate } \\
\text { and of wages increasing less than } \\
\text { general productivity levels. }\end{array}$ \\
\hline $\begin{array}{l}\text { Liberalisation of the capital account, and } \\
\text { a floating exchange rate. }\end{array}$ & $\begin{array}{l}\text { Floating exchange rate, but managed to } \\
\text { neutralise its tendency towards } \\
\text { overvaluation. }\end{array}$ \\
\hline $\begin{array}{l}\text { Growth financed with citizens' foreign } \\
\text { savings. }\end{array}$ & $\begin{array}{l}\text { Foreign savings improve the exchange } \\
\text { rate, and cause the substitution of foreign } \\
\text { for domestic savings. }\end{array}$ \\
\hline
\end{tabular}

Source: Bresser-Pereira (2009: 31).

While Tables 1 and 2 synthesise the economic policies and strategies adopted by the new developmentalism, post-neoliberalism also encompasses other policy areas and political ambitions. According to Grugel and Riggirozzi (2012: 2-3), Latin American post-neoliberalism has two distinctive pillars:

(...) the set of political aspirations centred on 'reclaiming' the authority of the state to oversee the construction of a new social consensus and approach to welfare, and the body of economic policies that seeks to enhance or 'rebuild' the capacity of the state to manage the market and the export economy in ways that not only ensure growth but are also responsive to social need and citizenship demands. 
This is why the idea of 'catching up with developed countries' is somewhat misleading. After all, while the development strategies of left-leaning governments in the region depend on export-led growth and increased domestic consumption, their overall ambitions transcend the mere revamping of state capitalism. They are also seeking to refashion the social contract and the nature and scope of collective responsibilities, and to question not only the conventional ways of promoting economic development, but also for whom it is conceived (Grugel and Riggirozzi 2012: 2-3). ${ }^{6}$

As noted earlier, the degree to which those strategies may be defined as market-driven varies widely. For instance, while regarding themselves as 'redeemers' (Krauze 2013), the Bolivarian governments proclaim that they are pursuing 'revolutions': Revolución Bolivariana (in Venezuela), Revolución Democrática y Cultural (in Bolivia), and Revolución Ciudadana (in Ecuador). Nevertheless, even when $21^{\text {st }}$-century socialism is the alleged goal, the 'pink tide' development strategies largely rest on the same foundations, namely large-scale raw materials production and exportation. ${ }^{7}$ The sustainability of these policies is an issue we will not pursue here. In this regard, the extent to which export expansion should or could be followed by broadening the domestic economic base is a key consideration, but for our purposes it suffices to recall that the region's new development model has also been defined as an extractive economy.

When it comes to understanding the extractivist nature of this model, new terms abound: 'neo-extractivism' (neoextrativismo), 'heterodox extractivism' (extrativismo heterodoxo), 'progressive extractivism' (extrativismo progressista), and others (Burchardt 2014). Neoextrativismo may be defined as a development model which aims to promote export-led economic growth, based upon the intensive exploitation of raw materials (mineral as well as agricultural commodities such as oil, gas, copper, soy beans, sugar 


\section{When Foreign Policy Meets Social Demands in}

cane, palm oil, and others ) - in other words, large-scale mining and monoculture. Those natural resources or their revenues are at least partially appropriated by the state, which then redistributes income in order to promote social inclusion and raise the living standards of the formerly underprivileged. This is why they are also described as 'compensating states' (Estados compensadores; Gudynas 2012; Stefanoni 2012).

According to Gudynas (2012), the Estado compensador should be distinguished from the traditional rentier state, which has frequently been understood as authoritarian or totalitarian, characterised as patrimonial, and sustained by transnational extractivism and local elites which capture the main share of state revenue, as there are no relevant redistributive policies. Following Stefanoni (2012: 53), extractivism tends to have the following consequences: (a) state institutions become fragile, and incapable of respecting the norms of and oversight by controlling state agencies and actors; (b) a lack of rules, transparency and accountability, which creates room for discretionary behaviour in managing public resources and common goods; (c) short-term policies and fragile state planning; and (d) the illusion of easy wealth, derived from the massive exploitation and exportation of primary goods.

While many have raised their voices against the supposed 'illusions of developmentalism' and its variations, we conclude this section by noting what Stefanoni (2012) called the 'communitarian illusions' currently being cultivated in the Andean region, notably in Bolivia and Ecuador, whose new constitutions feature the pursuit of 'vivir bien' and 'buen vivir' respectively. These terms, which are derived from the native languages Aymara and Quechua, and represent the contemporary aspirations of many Latin American peoples, may be defined as 'way of living in harmony with nature and with other human beings' (Hidalgo-Capitán and Cubillo-Guevara 2014: 26). What is said to be a 'communitarian illusion', or a sort of 'Andean 
utopia', according to some critics, may also be regarded as a central element of Latin American 'political epistemic insurgence' (Walsh 2010), or an emergent alternative to the prevailing ideas of development that is post-developmentalist, post-capitalist and post-socialist (see, for example, Artaraz and Calestani 2015; Faria 2015; Recasens 2014).

\section{Regional integration: co-operation and/as fragmentation}

While the leaders, movements and parties that became policy-makers after Latin America's 'turn to the left' frequently adopted nationalist rhetoric and policies, they did not neglect or undervalue the importance of foreign policy to post-liberal national projects. On the contrary, as noted by Gardini and Lambert (2011: 261), foreign policy 'increasingly seems to be a continuation of domestic politics by other means'. Brazilian foreign policy was one of the first policy domains to undergo far-reaching change after Lula's rise to power in 2003 (Pomar 2010). As discussed earlier, most of the dichotomies forged to reflect the full diversity of the 'pink tide' also rely on variables related to the new standing of some of those countries in international relations, such as the way in which the USA came to be regarded by their leaders, their attitudes towards free trade agreements, and the way in which globalisation has been understood and incorporated into governmental practices. By the same token, a study commissioned by the Network of Progressive Foundations of the Southern Cone (Red de Fundaciones Progresistas del Cono Sur) to identify convergences among the foreign policies of Argentina, Brazil, Chile and Uruguay found a degree of consensus about the following questions: the need for further integration beyond trade; the need to build stronger and broader political instruments for dealing with regional issues; the defence of 


\section{When Foreign Policy Meets Social Demands in}

Latin America

multilateralism and international law; and the reform of the international institutions established after World War Two. According to that publication, 'what seems to be a differential is the influence exerted by the left and progressive parties and/or sectors on foreign policy directives, which put pressure towards an integrationist, Latin American, and solidary orientation' (Budini 2010: 16). Furthermore, the return of the state at the domestic level, as discussed briefly in the previous section, was followed by a regained centrality of the state as the main promoter of regional development and projects (Gardini 2011).

In early $21^{\text {st- }}$ century Latin America, the strategies put forward to foster a 're-imagined national interest' in a rapidly changing international context were defined by at least three elements: the revival of the idea of regional autonomy through integration, paradoxically supported by nationalist thinkers and parties; the questioning of both globalisation and US political and economic dominance; and the pursuit of new development models and new kinds of international relations (Gardini and Lambert 2011: 4). The pivotal role that foreign policy was expected to play is therefore evident. As regionalism is both a key expression of and an important instrument for the promotion of these three objectives, the rest of this section will be dedicated to a panoramic appreciation of Latin American contemporary regionalisms. The plural term is mandatory here, as will quickly become clear.

Two preliminary propositions should be noted: (a) apart from Europe, 'Latin America is where regionalism has enjoyed the longest tradition and has arguably achieved the deepest and most sophisticated forms' (Gardini 2011: 235); and (b) one should pay attention to the 'oxymoronic character of Latin American regional integration: consistent yet chronically unstable, and resilient in spite of frequent crises' (Legler 2013: 332). As it is well known, the recognition of the importance of regional integration in Latin 
America is as old as the political independence of its nation states. That is why the ideas of the 'Bolivarian revolution' (which dates back to the early $19^{\text {th }}$ century) and Patria Grande ('the Great Homeland') are still so attractive today for many in Hispanic America, Brazil being a singular case in that regard (Spektor 2011). If Latin American regionalism enjoys a long tradition, its manifold institutional manifestations may have followed rationales that closely mirror the prevailing development models. This is no coincidence, as regional integration (or co-operation) must be understood as yet another tool of national development policy, particularly in a region such as Latin America where a conception of foreign policy as an instrument for promoting development is so firmly entrenched. Therefore, academic literature frequently identifies three phases in Latin American regionalism: 'closed regionalism' in the 1950s and 1960s; 'open' or 'neoliberal' regionalism in the 1980s and 1990s; and 'post-neoliberal' or 'post-hegemonic' regionalism in the $21^{\text {st }}$ century (Sanahuja 2009; Ribeiro and Kfuri 2010).

Closed regionalism, fostered in Latin America in the 1950s and 1960s by ECLAC, 'attempted to insulate the region from external competition through high trade barriers in order to pursue development by nurturing the local infant industry and by breaking dependence on foreign capital and technology' (Gardini 2015: 211). It was conceived as a key instrument of the import substitution development model. The Latin American Free Trade Association (1960), the Central American Common Market (1961), the Andean Pact (1969), and the Caribbean Community (1973) were its main institutional manifestations. Open regionalism followed as an offspring of post-Cold War neoliberal ideals. The Common Market of the South (MERCOSUR), established in 1991; the North American Free Trade Area (NAFTA), established in 1994; and the transformation of the Andean Pact into the Andean Community in 
When Foreign Policy Meets Social Demands in Latin America

1996) were institutional settings built under that rubric. Regional integration was expected to boost the capacity of Latin American countries to compete in global markets, open up their economies, and abandon the import substitution model. The institutions of the two previous phases, however, did not yield the expected economic and social improvements. 'Open regionalism' and the related attempts to attract foreign direct investment largely resulted in the dismantling of national business communities and the growth of transnational corporations. Besides that, Latin American countries became highly vulnerable to external oscillations, and the model seemed to contribute to the 'freezing of an exclusionary status quo' (Ribeiro and Kfuri 2010: 7).

But while two of the $20^{\text {th }}$ century regionalism waves involved nearly all the countries on the continent, the picture in the current century is quite different as well as paradoxical, as the new regional integration (or co-operation) initiatives have definitely produced, and attest to, Latin American fragmentation. The new century has witnessed the establishment of no less than four new regional or subregional institutions, namely the Bolivarian Alternative/Alliance for the Americas (ALBA), launched in 2004; the Union of South American Nations (UNASUR), launched in 2008; the Community of Latin American and Caribbean States (CELAC), launched in 2011; and the Pacific Alliance of 2012. Any attempt to describe what these institutions stand for will probably lead to the conclusion that the Pacific Alliance may have produced a new and profound regional East-West divide - one that resembles the Treaty of Tordesillas (1494), as suggested by former Chilean President Ricardo Lagos (Campodónico 2013).

Gardini (2015: 210) has wittily characterised this polyphonic scenery (note that most of the older institutions are still active, at least formally) as a form of 'modular regionalism'. According to him, ALBA was 'created as an attempt to unite Latin America in the 
resistance against free markets and the perceived evil side of US-sponsored international capitalism'; UNASUR 'marked the emergence of Brazilian regional and global status directing regional policy along the lines desired by Brasilia'; CELAC is a 'platform to allow the continent to speak with one voice in major international venues' (as it does not include the USA and Canada, Ecuadorian president Rafael Correa defined it ironically as 'the consensus without Washington'); and, finally, the Pacific Alliance, which unites 'those Latin American countries sharing the Pacific shore, good relations with the US, and a preference for free markets and liberal economics' (Chile, Colombia, Peru and Mexico).

Before exploring this exuberant institutional proliferation, let us briefly recall the main features of so-called post-neoliberal regionalism, after which we will draw attention to the limits of this canonical definition, and present an alternative. Lest readers have lost sight of our objective, this brings us to the core of the examination of the linkages between social demands and foreign policy in this special issue. This is so because any sort of regional policy has distributive domestic impacts, and therefore commands different standards of stakeholder mobilisation.

Latin American post-neoliberal regionalism is usually understood in the following terms: political and security agendas prevail over a more traditional emphasis on trade; regional institutions are meant to serve as platforms for development strategies or models that refute the prescriptions and expectations of the Washington Consensus; these institutions are regarded as supporting the objectives of the developmentalist state at the regional level; they support the fight against poverty, inequalities and asymmetries; and, finally, they promote the adoption of proactive policies in the fields of energy and infrastructure, as well as in South-South co-operation (Sanahuja 2009). But 'post-neoliberal' is not the only adjective used to qualify these new institutional experiments. The others, as discussed by 


\section{When Foreign Policy Meets Social Demands in}

Gardini (2015), not only highlight the various rationales that underpin their proliferation, but also suggest divergent explanations for their emergence. As the author puts it:

The key features of the contemporary picture, and the associated explanations for its emergence, can be summarized in six arguments and types: the overcome of open regionalism (post-neoliberal), enfranchisement from the US (post-hegemonic), increased international presence and networks (third generation), growing intricacy and juxtaposition (spaghetti bowl), gap between political narrative and reality (rhetorical regionalism), and preference for cooperation over traditional economic integration (peak of regionalism). All these approaches provide for credible, although not necessarily acceptable or exhaustive, explanations of the current situation or some aspects of it (Gardini 2015: 220).

But regional institutions are not monolithic, and some attempts have been made to revamp the older institutions' agendas in order to align them with prevailing preferences. MERCOSUR is a notorious example. Even if the bloc has lost momentum, despite its horizontal expansion to incorporate new associated and permanent members (Venezuela and Bolivia), it has also been reformed in order to absorb elements of the post-neoliberal agenda. Examples include the establishment of the MERCOSUR Structural Convergence Fund (2004), and the launch of Social and Productive MERCOSUR (2006). Nonetheless, 'MERCOSUR [has] proved to have limited ability to adapt to a changing environment' (Oelsner 2013: 124). ${ }^{8} \mathrm{It}$ is now widely accepted that MERCOSUR has not emerged from either increased economic interdependence (even if it later came to promote such a development) or social demands, and that it 'had not created a significant institutional structure' until recently (Malamud 2005: 139). If 'state-led, presidential-driven integration has been a 
persistent feature of Mercosur, as has been the low level of involvement of business organizations' (Malamud 2005: 139), it is reasonable to assume that the same applies to the other institutions making up the Latin American 'spaghetti bowl'. Malamud and Gardini (2012: 117) have correctly pointed out that 'segmented and overlapping regionalist projects [in Latin America] is not a manifestation of successful integration but, on the contrary, signals the exhaustion of its potential'. But if political co-ordination at the presidential level has been hampered by the fact that some of those institutions compete with each other (ALBA and UNASUR are frequently quoted examples), the new agenda has been successful in a number of ways, as illustrated by UNASUR's Defence Council. While Latin American integration is still largely presidentially driven, the functional co-operation and policy co-ordination promoted by UNASUR has 'floundered in some areas such as finance..., whereas in health it has made remarkable inroads and provided stepping stones to institutional development and a novel diplomacy' (Herrero and Tussie 2015: 262). According to the optimistic approach of these authors, UNASUR managed to promote a 'quiet revolution' in health diplomacy in South America.

To conclude this section, the image of a fragmented Latin America and of unsuccessful regional institutions that overlap and compete with each other is supported by extensive empirical evidence. However, a different picture emerges if: (a) we recall that the European experience, which currently faces unprecedented challenges in multiple domains, does not need to be regarded as a Weberian ideal-type; (b) if we are not seduced by the idea of a supposedly homogeneous Latin America, whose identity has been both praised and questioned; and (c) if we remember that the region is not currently trying to integrate itself, but, more modestly, simply to promote co-operation (Gardini 2015). In what follows, we will explore the less obvious connections between the social and political 
phenomena in question and the current study of Latin American foreign policies.

\section{Latin American foreign policy analysis (FPA)}

Rita Giacalone (2012) has argued that FPA in Latin America has been a relatively neglected area in recent years. After a broad review of work published in Argentina, Brazil, Chile, Colombia, Mexico and Venezuela since the 1970s, the author concludes that it remains an undertheorised field within the disciplines of political science and IR. FPA does not receive, for instance, the same level of coverage as issues of international political economy, as the enduring importance of Marxist-structuralist readings in Latin-American IR production testifies. Besides her general finding, Giacalone also recognises significant differences in FPA among the countries in question. She portrays Brazil as a pioneer, with Brazilian scholars developing more sophisticated approaches derived from sociological constructivism and post-modern theories. Importantly, she also identifies the different impacts of academics and their intellectual constructs on the foreign policies of their respective countries. While Brazilian researchers have managed to influence decision-makers, this has not happened in Argentina. However, it is not yet clear whether the quality of academic production and access to foreign policy decision-making are correlated (Giacalone 2012). Tickner's content analysis of IR theory teaching in Latin America shows that realist and liberal approaches are overwhelmingly favoured, followed by Marxist and neo-Marxist frameworks, notably dependency theory. Constructivist and post-positivist accounts of international affairs (including feminism, post-colonialism and post-structuralism) lag far behind, as they 'are absent from over one third of the IR theory courses analyzed and are given only passing attention in most of the 
Dawisson Belém Lopes and Carlos Aurélio Pimenta de Faria

other syllabi, adding up to less than 5 percent of the total readings' (Tickner 2009: 42).

Latin American FP analysts broadly agree that the USA has played a decisive role in the region (Amorim Neto 2011; Tickner 2015), and that national autonomy (identified as 'relative autonomy,' 'confrontational autonomy,' 'autonomy within dependence,' 'autonomy through participation', and so on) has been important in Argentina, Brazil, Chile, Colombia, Mexico, Peru, and Venezuela (Braveboy-Wagner 2008; Giacalone 2012). Policy proposals that have underestimated the weight of nationalism (such as 'peripheral realism' in Argentina and 'interdependence' in Mexico) have been short-lived, and have rapidly been transformed into anathemas in electoral campaigns. In an important contribution to the literature on linkages between domestic politics and foreign policy, Rafael Villa (2006) has argued that South American countries that have undergone institutional democratisation in recent years may still lack social 'democratic capital', which affects foreign policy formation in turn. According to him, "the low degree of continuity and institutionalization of the so-called "rules of the game" in various countries in the region, especially in the Andean Community, precludes a minimum of congruence between formal rationality (legally expressed in constitutions, clauses or decrees) and effective democratic practices' (Villa 2006: 82). Countries have also recently redemocratised in Central and Eastern Europe. These liberalised economies commonly resort to a model of public diplomacy which, according to György Szondi (2009), sounds more like an attempt to erase the past stains of authoritarianism and communism than anything else. It presents the countries in question as 'trustworthy', and 'an eligible candidate' for membership of regional institutions (notably the EU) and other international fora. It may also play a role in reconfiguring the identities of the peoples of Central and Eastern Europe, amid the difficult transition from autocratic regimes to representative democracies. 
When Foreign Policy Meets Social Demands in Latin America

So the trend for young democracies (like most Latin American countries), based on the empirical examples in the contemporary literature, seems to be the following: foreign policies with little or no social articulation may easily end up being manipulated by governments, as there are no consolidated democratic linkages between society and the state. However, we will not take for granted that the relative lack of studies of linkages between society and the state in respect of Latin American foreign policy merely reflects social ontology - that is, the alleged political apathy of Latin Americans about international political issues. We believe that, besides all the factors already listed in the literature, other theoretical, epistemological and methodological issues as well as issues related specifically to foreign policy have not yet been properly scrutinised. According to Arlene Tickner (2015), Morgenthauian realist assumptions about the state, statespersons, and the national interest have been selectively incorporated into existing analytical frameworks (primarily ECLAC and dependency thinking). Therefore, 'The hybrid model that emerged from mixing bits and pieces of US and Latin American theories created the foundations for a series of suppositions about Latin American foreign policy, peripheral state dependence and development that informed both academic and political practice throughout the region until the midto late 1980s' (Tickner 2015: 78).

Most of the literature follows a line of reasoning that has long been consolidated among Latin-Americanists. In sum, it tends to approach Latin American foreign policies from a perspective based on their empirical final outcomes - i.e., the policies themselves - thus disregarding the policy-making process. However, by analysing foreign policy-making backwards (i.e., by emphasising outcomes rather than processes), one tends to lose sight of the strategic choices of decision-makers at different moments of a given policy-making cycle. This would compromise the chances of identifying all the 
actors involved in a given policy-making process, and holding them accountable. Besides obfuscating the identities of specific decision-makers, this behaviourist model also fails to reveal how foreign policy is politically and institutionally constructed. In other words, behaviourism's chief mistake in respect of FPA is to depoliticise its own subject. Concurrently, one will often come across the deterministic reading of Latin American international politics offered by social structuralism. This results in a simplistic narrative about constrained possibilities for foreign policy-making in the region, which the following remarks by Charles Maynes, then an editor of Foreign Policy, seem to exemplify:

The likelihood is that the US will have to live in the future with a Latin America much less subject to its will than in the past. ... [F]inally, the United States will have to accept that its overwhelming dominance in the postwar period was unique. Because the European powers were so weak after the II World War, their influence in Latin America was temporarily but sharply diminished. Now they have regained their prewar strength and have returned to the hemisphere in a major way (Maynes 1983: vii).

In other words, in the early 1980s, the editor of a prestigious US international relations publication envisioned a 'changing of the guard' as the only option for Latin American politics: as US tutelage ended, a shared domination by Western Europe and perhaps the Soviet Union would begin. Either way, he completely disregarded the possibility of a break with core-periphery domination. Simply stated, his fallacious assumption is as follows: if a given country is located in Latin America, then its foreign policy should (and would) be subordinated to Western powers. 


\section{When Foreign Policy Meets Social Demands in Latin America}

\section{The need for new theoretical and conceptual frameworks}

Foreign policy formation in Latin America has changed drastically over the past two or three decades, notably in respect of the number of role players, and the spread of themes. While previously just a few politicians and bureaucrats were granted access to the inner circles of power, and allowed to play a part in foreign policy decision-making, a sizeable group of other stakeholders, from businessmen and labour unions to human rights movements and the media, have begun to play a significant role, demanding that their viewpoints and interests be taken into account. Far from being a homogeneous march toward the procedural democratisation of foreign policy, this has triggered some important trends, both in terms of social dynamics and policy outcomes. For example, researchers cannot contend that foreign policy practices in Latin America are still monopolised by foreign policy ministries and diplomatic agents without this being promptly contested by their peers.

To start with, one must recall how Latin Americans saw foreign policy-makers in the early $20^{\text {th }}$ century. The diplomatic corps was portrayed as a group of affluent, well-born people whose mannerisms approximated those of courtesans at Versailles under Louis XIV. Moreover, unless an external factor had vital implications for domestic politics - as in the case of a declaration of war - Latin American presidents seldom involved themselves in foreign policy, and delegated this competence to their foreign ministers and/or diplomatic representatives. Unsurprisingly, presented with this combination of elitism and presidential apathy, people would feel increasingly removed from international politics, and nurture very little sympathy for foreign affairs (Dahl 2001). All this helps to clarify why foreign policy in Latin America rarely sought legitimacy from 
those citizens whose interests it was meant to represent. Opacity and a lack of social responsiveness would follow suit.

Cason and Power (2009) developed an influential explanation of this - arguably changing - state of affairs, with reference to Brazil. According to them, Brazil displayed two contrasting - albeit complementary - trends in respect of foreign policy after its transition to democracy in the 1980s: an unparalleled multiplication of stakeholders in policy-making; and, counter-intuitively, a concentration of diplomatic competencies in the hands of presidents (known as 'presidential diplomacy'). The ministry of foreign affairs, along with traditional diplomatic institutions (embassies, consulates, diplomatic academies, and so on) ran the risk of becoming obsolete, and ultimately dysfunctional. Although this narrative was informed entirely by Brazil's recent experiences in international affairs, its underlying logic seems to be applicable to other Latin American countries. Is that really the case? Or are we just overstretching and deforming Cason's and Power's argument?

A glance at the current social and political settings in Latin America quickly proves them wrong - even in respect of Brazil. A reality check delivers a far more complex and nuanced picture of Latin American foreign policy formation, featuring old and new players, and traditional and emergent questions. While there may still be room for anachronistic protocols and legal principles, many long-established foreign policy traditions are being replaced by others, in a pragmatic response to the new social inputs and actors that help to shape foreign policy. Formal and informal perspectives are blended by decision-makers, to the extent that external threats have become far more difficult to ward off. Thus, state and society in contemporary Latin America are compelled to build a more productive and fluent dialogue, lest foreign policy fails to do what it is meant to do (for examples of this emerging landscape, see other contributions to this special issue). 
When Foreign Policy Meets Social Demands in Latin America

A first symptom of change in Latin American foreign policies was the so-called horizontalisation of foreign policy-making. This term usually refers to the substitution of an old paradigm - in which ministries of foreign affairs functioned as international relations gatekeepers - by a new one, marked by the decentralisation of foreign policy implementation and a better distribution of tasks among different state bureaucracies (França and Badin 2010; Farias and Ramanzini 2015). This is happening in Argentina, Brazil, Mexico, and, to a lesser extent, Chile (see Busso, Coronado, and Aranda in this volume).

An important new player in Latin American foreign policy-making is the private sector. While maintaining diverse relationships with their governments and countries of origin, business people in Latin America have definitely gained ground in the past two decades, especially in more liberally oriented economies such as Chile, Colombia and Mexico. When it comes to foreign policy-making, the Chilean case attracts attention insofar as linkages between the ministry of foreign affairs and business people have been robustly institutionalised, as evidenced by the establishment of the Directorate-General of International Economic Relations (DIRECON). By contrast, the private sector in Venezuela does not enjoy much leverage in foreign policy, given the overwhelming impact of the Venezuelan state apparatus - notably the state-owned oil company PDVSA - over its economy (see Aranda, Mijares and Romero in this volume).

One more piece of evidence which supports the case for a renewed set of FPA tools is the appearance of a multitude of NGOs, notably the human rights and environmental groups emerging in the aftermath of dictatorial regimes, particularly in Argentina and Chile (see Busso and Aranda in this volume). Subnational as well as parliamentarian agents now rehearse to play a bigger role in foreign policy-making, especially in Brazil, Colombia and Mexico (see 
Feliú and Pinheiro and Rodrigues in this volume), but lag behind the mighty executive branch in the context of 'imperial presidentialism' (Faria 2012). The media have begun to exert growing pressure on policy-makers in the last few decades, as demonstrated by editorials and opinion pieces, particularly in Brazil and Argentina (see Mesquita and Medeiros in this volume). Academics play a minor but significant role in defining foreign policy issues, as exemplified by Escudé in Argentina, Castañeda in Mexico, Muñoz and Maira in Chile, and Lafer and Garcia in Brazil. Last but not least, ethnic groups - indigenous peoples in the Andes, blacks in Brazil and Venezuela - have finally been accepted as legitimate stakeholders in the realm of foreign policy, albeit for electoral or symbolic reasons, at a time when diplomacy and democracy have finally begun to resonate with one another.

One should also consider China's global rise, and its influence over Latin American economies, in order to fully grasp what is at stake in the domain of foreign policy-making. Given that Brazil and Argentina now have China as a major foreign trading partner, while Mexico has retained its preferential commercial ties with the USA via NAFTA, one is tempted to interpret contemporary Latin American politics as a new Cold War story which once again opposes blues and reds. This temptation should be resisted, as we would run the risk of missing the main story in favour of a flawed and anachronistic one.

\section{About this issue}

This special issue of Contexto Internacional seeks to shed light on key factors in the complex amalgam of foreign policy and social demands in Latin America. To kick off, we present five broader narratives about how some of its greatest countries - Argentina, Brazil, Chile, Mexico and Venezuela - have dealt with the emergence of new actors and themes in foreign policy-making 
When Foreign Policy Meets Social Demands in Latin America

during the past 20 years. Megan Pickup explains Brazil's strategic choices in respect of South-South partnerships over the past decade and a half, while Anabella Busso and Gilberto Aranda focus on Argentina's and Chile's foreign policies in the Kirchner era and after Pinochet's rule. Maria-Esther Coronado illuminates how the Mexican federal bureaucracy handled a recent public health emergency via delicate negotiations with its NAFTA partners. Victor Mijares and Carlos Romero analyse Venezuela's polemic transition from Chávez to Maduro from the domestic as well as the diplomatic viewpoints. All the authors present convincing accounts of distinctive national contexts and social processes, fuelled by loads of empirical evidence and in-depth commentaries. By linking academic savvy with hard research, they have crafted precise and reliable reference material to politically controversial issues.

Three other articles focus on Brazil's recent foreign policy and its social connections. Daniel Cardoso explores the concept of 'network governance' in order to deliver a sharp assessment of Brazil's China policy at the start of the $21^{\text {st }}$ century. Daniel Castelan tells a detailed story about the liberalisation of the Brazilian economy in the 1990s, and the positions sustained by interest groups during the Free Trade Area of the Americas (FTAA) negotiations - a vital issue for Brasília at the time. Rafael Mesquita and Marcelo Medeiros examine the varied responses in the local and foreign media to Brazilian international initiatives, notably its approach to Haiti in 2004 and Iran in 2010. Two other articles compare Brazil with other Latin American states: Carola Lustig and Tomás Olego investigate Argentine public opinion about Brazil's ascendancy in South America, and reach curious and elucidating findings, while Vinícius Rodrigues engages in an interesting debate about how Mexican and Brazilian civil society have been provided with some procedural authority but not with 'substantial legitimacy' in current foreign policy-making processes. 
Two research teams from the Universidade de São Paulo have contributed comparative analyses of public opinion and legislative behaviour in respect of foreign policy in various Latin American countries. Janina Onuki, Fernando Mourón and Francisco Urdínez analyse Brazil's putative regional leadership role and the reactions to it in seven Latin American countries. Pedro Feliú and Flávio Pinheiro test a few canonical hypotheses to come up with conclusions which meaningfully advance legislative studies of foreign policy in Latin America. Last but not least, the world-class scholar Andrés Malamud comments perceptively and provocatively on the texts that make up this very special issue of Contexto Internacional.

\section{References}

Amorim Neto, Octavio. 2011. De Dutra a Lula: a condução e os determinantes da política externa brasileira. Rio de Janeiro: Elsevier.

Artaraz, Kepa and Melania Calestani. 2015. 'Suma qamanã in Bolivia: indigenous understandings of well-being and their contribution to a post-neoliberal paradigm'. Latin American Perspectives, Issue 204, 42 (5): 216-233.

Belém Lopes, Dawisson. 2007. 'Relações econômicas internacionais, isomorfismo institucional e democracia na América Latina'. Dados 50(3): 611-652.

2014. 'Políticas sociais e potência à brasileira'. Revista Estudos Políticos 5(1): 27-39.

Bielschowsky, R. 2002. O Ciclo Ideológico do Desenvolvimentismo. Rio de Janeiro: Contraponto.

Botto, Mercedes Isabel. 2011. ¿Qué nos enseñan los 20 años del Mercosur? Nueva Sociedad 232. 


\section{When Foreign Policy Meets Social Demands in}

Latin America

Braveboy-Wagner, Jacqueline Anne. 2008. Small States in Global Affairs: the Foreign Policies of the Caribbean Community. New York: Palgrave.

Bresser-Pereira, Luiz Carlos. 2009. 'From old to new developmentalism in Latin America'. Textos para Discussão No 193. FGV/EESP.

Budini, Terra Friedrich. 2010. 'A construção de consensos progressistas na política externa dos governos de Argentina, Brasil, Chile e Uruguai’. In Yesko Quiroga, Cassio França (eds). Consenso progresista: Política exterior de los gobiernos progresistas del Cono Sur: consensos y desafíos. São Paulo: Fundación Friedrich Ebert. pp. 11-34.

Burchardt, Hans-Jurgen. 2014. Logros y contradicciones del extractivismo: Bases para una fundamentación empírica y analítica. Friedrich Ebert Stiftung/Nueva Sociedad. Available at: <http://nuso.org/media/documents/ Logros_y_contradicciones_del_extractivismo._Bases_para_una_fundamenta ci\%C3\%B3n_emp\%C3\%ADrica_y_anal\%C3\%ADtica_Febrero_2014.pdf> [accessed on 5 May 2016].

Cameron, Maxwell A. 2009. 'Latin America's left turns: beyond good and bad'. Third World Quarterly 30(2): 331-348.

Campodónico, Humberto. 2013. ‘¿De vuelta a Tordesillas?’, La Republica.pe, 2 December. Available at: <http://larepublica.pe/columnistas/cristal-demira/de-vuelta-a-tordesillas-02-12-2013> [accessed on 5 May 2016].

Cason Jeffrey W and Timothy J Power. 2009. 'Presidentialization, pluralization, and the rollback of Itamaraty: explaining change in Brazilian foreign policy-making in the Cardoso-Lula era'. International Political Science Review 30(2): 117-140.

Castañeda, Jorge G. 2006. 'Latin America's left turn'. Foreign Affairs 83(3).

2016. 'The death of the Latin American left'. The New York Times 22 March.

Corrales, Javier. 2012. 'Neoliberalism and its alternatives'. In Peter Kingstone and Deborah Yashar (eds). Handbook of Latin American Politics. New York: Routledge. pp. 133-157.

Economic Commission for Latin America and the Caribbean (ECLAC). 2007. Economic Growth with Equity: Challenges for Latin America. Santiago de Chile. 


\section{Dawisson Belém Lopes and Carlos Aurélio Pimenta de Faria}

Escudé, Carlos. 2015. 'Realism in the periphery'. In Jorge I Domínguez and Ana Covarrubias (eds). Routledge Handbook of Latin America in the World. New York: Routledge. pp. 45-57.

Faria, Carlos Aurélio Pimenta. 1998. 'Uma Genealogia das Teorias e Tipologias do Estado de Bem-estar Social'. Revista Brasileira de Informação Bibliográfica em Ciências Sociais (BIB) 46: 38-71.

2012. 'O Itamaraty e a Política Externa Brasileira: Do Insulamento à

Busca de Coordenação dos Atores Governamentais e de Cooperação com os Agentes Societários'. Contexto Internacional 34(1).

2015. 'Sumak Kawsay ou Buen Vivir? Os novos fundamentos constitucionais nativos e a reforma das políticas sociais no Equador da "Revolução Cidadã"'. Paper presented at 39 Annual Meeting of ANPOCS, Caxambu, Brazil, October.

Faria, Carlos Aurélio Pimenta and Clarisse Goulart Paradis. 2013. 'Humanism and solidarity in Brazilian foreign policy under Lula (2003-2010): theory and practice'. Brazilian Political Science Review 7(2): 8-36.

Farias, Rogério de Souza and Haroldo Ramanzini Júnior. 2015. 'Reviewing horizontalization: the challenge of analysis in Brazilian foreign policy'. Revista Brasileira de Política Internacional 58 (2): 5-22.

Flores-Macías, Gustavo A. 2010. 'Statist vs pro-market: explaining leftist governments' economic policies in Latin America'. Comparative Politics 42 (4).

França, Cassio Luiz and Michelle Ratton Sanchez Badin. 2010. A inserção internacional do poder executive federal. São Paulo: Friedrich Ebert Siftung.

Gardini, Gian Luca. 2011. 'Unity and diversity in Latin American visions of regional integration'. In G L Gardini and P Lambert (eds), Latin American Foreign Policies: Between Ideology and Pragmatism. New York: Palgrave Macmillan. 235-254.

2015. 'Towards modular regionalism: the proliferation of Latin American cooperation'. Revista Brasileira de Política Internacional 58(1): 210-229.

Gardini, Gian Luca and Peter Lambert (eds). 2011. Latin American Foreign Policies. Between Ideology and Pragmatism. New York: Palgrave Macmillan. 


\section{When Foreign Policy Meets Social Demands in}

Latin America

Giacalone, Rita. 2012. 'Latin American foreign policy analysis: external influences and internal circumstances'. Foreign Policy Analysis doi 10.1111/j.1743-8594.2011.00176.x.

Grugel, Jean and Pía Riggirozzi. 2012. 'Post-neoliberalism in Latin America: rebuilding and reclaiming the state after crisis'. Development and Change 43 (1): 2012 .

Gudynas, Eduardo. 2012. 'Estado compensador y nuevos extractivismos: Las ambivalencias del progresismo sudamericano'. Nueva Sociedad 237: 128-146.

Herrero María Belén and Diana Tussie. 2015. 'UNASUR Health: a quiet revolution in health diplomacy in South America'. Global Social Policy 15(3): 261-277.

Hidalgo-Capitán, Antonio Luis and Ana Patricia Cubillo-Guevara. 2014. 'Seis Debates Abiertos sobre el Sumak Kawsay'. Íconos Revista de Ciencias Sociales 48.

Karl, Terry Lynn. 1997. The Paradox of Plenty: Oil Booms and Petro-states. Berkeley: University of California Press.

Krauze, Enrique. 2013. Os redentores. Ideias e poder na América Latina. São Paulo: Benvirá.

Lanzaro, Jorge. 2007. 'Gobiernos de izquierdaen América Latina: entre el populismo y la social democracia: una tipologia para avanzar em elanálisis comparado'. Análise de Conjuntura OPSA, 12. Dezember.

Legler, Thomas. 2013. 'Post-hegemonic regionalism and sovereignty in Latin America: optimists, skeptics, and an emerging research agenda'. Contexto Internacional 35(2): 325-352.

Malamud, Andrés. 2005. 'Presidential diplomacy and the institutional underpinning of Mercosur: an empirical examination'. Latin American Research Review 40(1): 138-164.

Malamud, Andrés and Gian Luca Gardini. 2012. 'Has regionalism peaked?: the Latin American quagmire and its lessons'. The International Spectator: Italian Journal of International Affairs 47 (1): 116-133.

Maynes, Charles William. 1983. 'Foreword'. In Staff of Foreign Policy (eds). Foreign Policy on Latin America (1970-1980). Boulder: Westview Press. 


\section{Dawisson Belém Lopes and Carlos Aurélio Pimenta de Faria}

Mires, Fernando. 2008. 'Socialismo nacional versus democracia social: Una breve revisión histórica'. Nueva Sociedad 217.

Nassuno, Marianne. 1999. 'O controle social nas organizações sociais no Brasil'. In Luiz Carlos Bresser-Pereira and Nuria Cunill Grau (eds). O Público Não-estatal na Reforma do Estado. Rio de Janeiro: FGV.

Oelsner, Andrea. 2013. 'The institutional identity of regional organizations, or Mercosur's identity crisis'. International Studies Quarterly 57 (1): 115-127.

Oppenheimer, Andres. 2015. 'The fall of Brazil, Argentina and Venezuela'. Miami Herald, 10 October.

Paniza, Francisco. 2006. 'La marea rosa'. Análise de Conjuntura OPSA, 8.

Petkoff, Teodoro. 2005. 'Las dos izquierdas'. Nueva Sociedad 197.

Pogrebinschi, Thamy. 2013. El Giro Pragmático de la Democracia en América Latina. Friedrich Ebert Stiftung/Nueva Sociedad, Análisis. Available at http://library.fes.de/pdf-files/nuso/10084.pdf.

Pomar, Valter. 2010. 'A política externa do Brasil'. In Yesko Quiroga and Cassio França. (eds). Consenso progresista. Política exterior de los gobiernos progresistas del Cono Sur: consensos y desafios. São Paulo: Fundación Friedrich Ebert. pp. 63-96.

Recasens, Andreu Viola. 2014. 'Discursos "pachamamistas" versus politicas desarollistas: el debate sobre el Sumak Kawsay en los Andes'. Íconos Revista de Ciencias Sociales, 48: 55-72.

Ribeiro, Daniela and Regina Kfuri. 2010. 'A nova integração regional e a expansão do capitalismo Brasileiro na América do Sul'. Rio de Janeiro, OPSA, Observador Online 5 (4).

Rouquié, Alain. 2007. 'La democracia hoy: eljardin de lossenderos que se bifurcan'. Temas y Debates 13.

Sanahuja, José Antonio. 2009. 'Del "regionalismo abierto" al "regionalismo post-liberal": Crisis y cambio en la integración regional en América Latina'. In CRIES, Anuario de la Integración Regional de América Latina y el Gran Caribe, 7: 12-54.

Silva, Fabricio Pereira. 2014. 'Quinze anos da onda rosa latino-americana: balanço e perspectivas'. Observador online / OPSA 9 (12). 


\section{When Foreign Policy Meets Social Demands in}

Latin America

_ 2010. 'Esquerdas latino-americanas uma tipologia é possível?' Revista Oikos 9 (2).

Spektor, Matias. 2001. 'O regionalismo do Brasil'. Working Paper n.16, Plataforma Democrática. Available at: <http://www.plataformademocratica. org/arquivos/plataforma_democratica_working_paper_16_2011_portugues.p df $>$ [aceesed on May 2016].

Stefanoni, Pablo. 2012. 'Posneoliberalismo cuesta arriba: los modelos de Venezuela, Bolivia y Ecuador en debate'. Nueva Sociedad 239.

Szondi, György. 2009. 'Central and Eastern European public diplomacy: a transitional perspective on national reputation management'. In Nancy Snow and Phillip M Taylor (eds). Routledge Handbook of Public Diplomacy. New York: Routledge. pp. 292-313.

Tickner Arlene B. 2009. 'Latin America: still policy dependent after all these years?' In Arlene B Tickner and Ole Waever (eds), International Relations Scholarship around the World. New York: Routledge. pp. 32-52.

2015. Autonomy and Latin American international relations thinking. In Jorge I Domínguez and Ana Covarrubias (eds). Routledge Handbook of Latin America in the World. New York: Routledge. pp. 74-84.

Torre, Carlos de la. 2013. 'In the name of the people: democratization, popular organizations, and populism in Venezuela, Bolivia and Ecuador'. European Review of Latin American and Caribbean Studies 95: 27-48.

UNDP. 2004. Informe La Democracia en América Latina - Hacia una Democracia de Ciudadanos y Ciudadanas. Available at: <http://www. democracia.undp.org > [accessed on 3 March 2016].

Villa Rafael Duarte. 2006. 'Política externa brasileira: capital social e discurso democrático na América do Sul'. Revista Brasileira de Ciências Sociais 21: 63-89.

Walsh, Catherine. 2010. 'Political epistemic insurgency, social movements, and the refounding of the state'. In Mabel Moraña and Bret Gustafson (eds). Rethinking Intellectuals in Latin America. Madrid: Iberoamericana. pp. 199-211.

Weyland, Kurt. 1998. 'Swallowing the bitter pill: sources of popular support for neoliberal reform in Latin America'. Comparative Political Studies 31(5): 539-568. 


\section{Dawisson Belém Lopes and Carlos Aurélio Pimenta de Faria}

2009. 'The rise of Latin America's two lefts: insights from rentier state theory'. Comparative Politics 41 (2).

\section{NOTES}

1. We follow Silva (2014), who also chose not to discuss whether or not the governments of Lázaro Cárdenas in Mexico and Jacobo Arbenz in Guatemala should be considered as leftist.

2. For two fresh media treatments see Oppenheimer (2015) and Castañeda (2016).

3. According to Cameron, 'Dichotomising the left serves a disciplinary purpose, however; to distract attention from the failures of neoliberalism, the poor performance of democratic governments, and the waning influence of the United States' (Cameron 2009: 345).

4. Not all analysts agree with this polar opposition. Cameron, for instance, portrays a different picture: 'Many of the leaders associated with the electoral shifts to the left since 1998 continue to favor market-oriented policies, and none advocate centrally controlled economies based on planning. The backlash against neoliberalism does not signal a rejection of markets, but a repudiation of the ideology that places markets at the center of the development model to the detriment of public institutions and their social context' (Cameron 2009: 339).

5. As consensus is a rare flower in the discussion about the 'pink tide', this statement should be contrasted with the following: 'Whereas Latin America was a world champion of neoliberal reforms in the 1990s, in the 2000s it was the radical left that became world champion, but this time, in the direction of reversing economic freedoms" (Corrales 2012: 149).

6. Government slogans are meant to be telling: 'Ahora Venezuela es de todos' ('Now Venezuela is for all'); 'Brasil, um país de todos' ('Brazil, a country for all'); 'La pátria ya es de todos' ('The nation is already for all [Ecuadorians]').

7. Rentier state theory explains these governments' radicalisation as a product of the commodities bonanza. The 'paradox of plenty' (Karl 1997) or 'resource curse' has been widely analysed, and it scarcely needs to be restated that this does not occur in Latin America alone. 
8. For a more optimistic version of MERCOSUR's evolution, see Botto (2011). However, the author emphasises that the commercial agenda is still dominant.

\section{About the authors}

Dawisson Belém Lopes is a tenured professor of international and comparative politics, a faculty member of the School of Humanities of the Federal University of Minas Gerais (UFMG, Brazil), and a researcher at the National Council for Scientific and Technological Development (CNPq) of Brazil. His current research centres on Latin American politics, and the intricate relationship between intergovernmental organisations and the democratisation of the global order. He is the author of two books on contemporary Brazilian foreign policy.

Carlos Aurélio Pimenta de Faria is a professor of foreign policy analysis and Brazilian foreign policy at the Pontifical Catholic University of Minas Gerais (PUC Minas, Brazil), and a researcher at the National Council for Scientific and Technological Development (CNPq) of Brazil. He has edited books on public policy diffusion, new public policy actors and processes in Latin America, public policy as a multidisciplinary field, and federalism and public policy in Brazil. 